a matter of military strength, but there is as yet no reason to believe that the proper management of the global environment will be free from difficulties of the kind that have plagued arms control over the decades - chauvinism, prevarication, fecklessness and downright selfishness. That is where the Pugwash experience could be invaluable.

$\square$

\section{Everything is money}

\section{Finance ministers should not be surprised that their economies seem uncontrollable.}

THE best part of a decade ago, the variety of economists called monetarists came into the ascendancy in several places with a simple and beguiling recipe for running the money affairs of modern states, themselves tired of a decade of inflation. The monetarist recipe is what the name implies: control the supply of money in people's pockets, they said, and you will regulate the economy. If, for example, the supply of money is constant but there are more goods for sale in the shops, prices will decline because one supply must requite the other (which is broadly speaking true, provided that the speed at which money circulates is not increased). On both sides of the Atlantic and, now, in Australasia as well, versions of this recipe have been successfully applied to beat back inflation without bringing economic growth to a dead stop. So why are monetarists not now hailed as protectors of the modern state, saviours of civilization everywhere? Because ordinary people, in their ordinary ways, turned out to be too smart.

The dilemma is illustrated by what has gone wrong in Britain and the United States. The British case is the simpler, involving an over-simple definition of what constitutes money. In 1979, the newly elected government imposed on itself (and its voters) the discipline of limiting the growth of a quantity called 'M3', essentially the sum of the total cash in people's pockets and instruments such as bank deposits they could quickly turn into cash. By three years ago, the target was manifestly too low and was abandoned on the grounds that, with the British economy in better shape than for decades, the fault must lie with the target, not economic policy. Having begun this year by selling pounds for dollars so as to prevent their value increasing, the monetary authorities are now probably on the opposite tack, buying pounds to sustain sterling because people fear that inflation is on the way back. What has gone wrong?

Over short periods of time, the cash in people's pockets and banks may accurately measure spending power, but not when timescales lengthen. Indeed, given time enough, people can turn virtually any asset into spending power, either by selling it or by using it as collateral for a loan from the bank. Even expectations (the prospect of a better job, the sudden illness of a wealthy aunt) are bankable. Ordinarily there are limits to the amount of spending power that can be generated like this, but the British have evaded them by playing a real-life version of the game 'Monopoly' with each others' houses, driving up prices with the help of tax-breaks on mortgages, making everybody feel wealthy and filling many pockets with the real stuff. The government is now trying to put out the fire by increasing interest rates, but it should be tackling the trouble at source.

In the United States, affairs are more complicated. The now outgoing administration first cut taxes, creating a sense of wellbeing, putting more money into pockets - and then borrowing it back to cover the federal deficit. The snag is that the assets, say Treasury bonds, acquired in return seem like wealth even though the government may not be ready to redeem them (and they are certainly bankable). So the United States has run up a trade deficit as well as a federal deficit because the government, like the British, did not appreciate that people who want to spend money will find ways of doing so, whatever the statistics say. The process has entailed the sale of a large slice of US industry to people from overseas. Soon, it will have to stop.

\section{Tricks to order}

US regulators offer sensible guidelines for investigating fraud, but should keep their distance.

ScIENTIFIC misconduct as now defined (see page 195) is not new, only the likelihood that there will now be legislation on the subject in the United States. It has always been likely that the whiffs and puffs of laboratory scandal in the past few years would dangerously attract attention among the federal agencies and in the Congress. Now those chickens are coming home to roost. The Department of Health and Human Services (HHS) plans to take over from the National Institutes of Health the management of the investigation of alleged fraud in the scientific literature. No doubt mounting interest in the Congress has left it with little choice. But HHS appears not to appreciate how serious will be the implications of its proposals.

As HHS itself acknowledges, what is now called scientific fraud is not fraud in the ordinary sense. Most criminals convicted under this heading have deceived others for the sake of tangible gain, usually a pot of money. Although there have been some cases in which scientists have been accused of deception for the sake of monetary gain, the more effective exploitation of a patent, perhaps, the cases in the front of the mind of Congress have been aimed at other goals - a published paper, other marks of professional esteem and even professional promotion. The victims in these cases are the scientific community at large, which is cheated, close professional colleagues (who may be damaged by association), the institutions that employ the fabricators and plagiarists - and the people themselves, at least if they are found out. Technically the grant-making agencies are also deceived, which is why HHS enters the suit.

As they are, the regulations HHS proposes are sensible. It is a splendid idea that, if there is to be an investigation of misconduct, it should be quick. Delayed or prolonged inquiries help private and public relationships to fester. (Delay is also not always distinguishable from avoidance.) Institutions faced with the need to investigate allegations against one of their members should prudently call on outsiders to do what is bound to be a distasteful and thankless job. And so on. If HHS confines itself to overseeing these processes, not carrying them out itself, not much extra damage will be done. The danger is that Congress will push the agencies into a more inquisitorial role, or even assume such a role itself.

That would be disastrous. For what the world at large does not appreciate is that, except for the most flamboyant cases of fraud, there is no certain way of distinguishing between malevolence and honest error, which is as unavoidable in research as in any other profession. It is even forgivable, given the emotional attachment to his creation of the author of a piece of research or of a report thereon, that he should be reluctant to withdraw. If under the new regime or some other, people who make honest mistakes are to be prosecuted with the zeal that should attach to those who set out to cheat, that will sour the atmosphere of productive laboratories. But there can be no question that the only sure judges of a person's motives are his or her colleagues, the closer the better. For all their virtues in other fields, members of the Congress are not well-equipped for these sombre tasks, which works against the doctrine that the assessors should be independent.

The moral is that the Congress should stay away from the administration of these matters, contenting itself with an occasional retrospective inquiry into the way in which institu-tions look into cases brought to light. In any case, there are other cases more directly in the purview of Congress where miscalculation has cost taxpayers real money (the B-2 bomnber development or, for that matter, the search for $Z^{0}$ and $W \pm$ mesons at the Stanford Linear Accelerator Center). To pretend that science could be infallible is foolish, but to behave as if discovery can be regulated by judicial rules is downright wrong. 